\title{
PENERAPAN METODE PEMBELAJARAN BERBASIS OUTDOOR LEARNING DALAM PELAJARAN MENGONSTRUKSI TEKS LAPORAN HASIL OBSERVASI PADA SISWA KELAS VII SMP NEGERI 1 TELAGA
}

\author{
Novianti umamit ${ }^{1 *}$, Fatmah AR. Umar ${ }^{2 * *}$, Muslimin $^{3 * * * *}$
}

\section{Info Artikel}

Sejarah Artikel:

Diterima Februari 2021

Disetujui Maret 2021

Dipublikasikan Mei 2021

\begin{abstract}
This study was determined to apply the outdoor learning-based learning methods in the lesson of constructing observation result report text for the seventh-grade students of SMPN 1 Telaga. The research problems of this study were (1) the application of outdoor learning-based learning methods in constructing the observation report texts at seventh-grade students of SMPN 1 Telaga, (2) the obstacles faced during the implementation of the methods (3) and efforts to overcome the application of the aforementioned learning methods. The results of applying the outdoor learning-based learning method in compiling observation result report text for seventh-grade students indicated that the researcher applied the material by adjusting the lesson plans. The implementation process was the introduction, perception, lesson explanation, delivery of outdoor learning-based learning methods, and a group division. Furthermore, at the main activity stage, the researcher utilized sources/media outside the classroom, carried out reflection activities, and provides conclusions on the material that has been taught.
\end{abstract}

Keywords: Application, Outdoor Learning, Constructing Observation Result Report Text

\footnotetext{
Alamat Korespondensi:

Universitas Negeri Gorontalo, Jln. Sudirman No. 6 Kota Gorontalo noviantiumamit11@gmail.com; faruung@gmail.com; musiyan82@gmail.com
} 


\section{ABSTRAK}

Peneliti ini bertujuan untuk penerapan metode pembelajaran berbasis outdoor learning dalam pelajaran mengonstruksi teks laporan hasil observasi pada siswa kelas VII SMP Negeri 1 Telaga. Permasalahan dalam penelitian ini adalah (1) bagaimanakah penerapan metode pembelajaran berbasis outdoor learning dalam pelajaran mengonstruksi teks laporan hasil observasi pada siswa kelas VII SMP Negeri 1 Telaga, (2) bagaimanakah kendala yang di hadapi dalam penerapan metode pembelajaran berbasis outdoor learning dalam pelajaran mengonstruksi teks laporan hasil observasi pada siswa kelas VII Smp Negeri 1 Telaga, dan (3) bagaimanakah upaya dalam mengatasi penerapan metode pembelajaran berbasis outdoor learning dalam pelajaran mengonstruksi teks laporan hasil observasi pada siswa kelas VII SMP Negeri 1 Telaga. Hasil penelitian menunjukkan bahwa penelitian penerapan metode pembelajaran berbasis outdoor learning dalam pelajaran mengonstruksi teks laporan hasil observasi pada siswa kelas VII SMP Negeri 1 Telaga. Dalam penelitian ini, peneliti menerapkan materi dengan menyesuaikan RPP. Adapun penerapannya ialah pendahuluan, melakukan apresepsi, menjelaskan materi, penyampaian tentang metode outdoor learning, dan pembagian kelompok. Pada tahap kegiatan inti, peneliti memanfaatkan sumber/media di luar kelas, melaksanakan kegiatan refleksi, dan memberikan kesimpulan materi yang telah di ajarkan.

Kata kunci: Penerapan, Outdoor Learning, Mengonstruksi Teks Laporan Hasil Observasi 


\section{PENDAHULUAN}

Pembelajaran di luar kelas (outdoor learning) merupakan upaya untuk mengarahkan siswa untuk melakukan aktivitas yang dapat membawa mereka mengamati lingkungan sekitar, sesuai dengan materi yang diajarkan. Sehingga, pendidikan di luar kelas lebih mengarah terhadap pengalaman dan pendidikan lingkungan yang sangat berpengaruh pada kecerdasan siswa (Yumnah, dkk, 2019:1).

Lingkungan di luar ruangan secara alami mendorong interaksi di antara sesama anak ataupun di antara orang dewasa dan anak-anak. Dengan interaksi ini, maka keterampilan sosial mereka dapat dikembangkan. Dengan bermain dilingkungan terbuka, siswa-siswa dapat belajar mengenal lingkungan sosial masyarakat terdekat ataupun lingkungan sekolah.

Suatu pembelajaran yang baik adalah apabila melibatkan siswa secara aktif dalam proses pembelajaran, misalnya mengajak siswa untuk belajar di luar kelas sehingga siswa dapat berpartisipasi aktif langsung dalam pembelajaran.

Menurut Yuliarto (dalam Husamah, 2013:18) kejenuhan pengembangan di dalam ruang turut memberikan dorongan berkembangnya konsep pendidikan di luar kelas. Pendidikan dalam ruang yang bersifat kaku dan formal dapat menimbulkan kebosanan, termasuk juga kejenuhan terhadap rutinitas di sekolah. Pendidikan luar kelas dijadikan sebagai alternatif baru dalam meningkatkan pengetahuan dalam pencapaian kualitas manusia. Alam sebagai media pendidikan adalah suatu sarana efektif untuk meningkatkan pengetahuan dan mengembangkan pola pikir serta sikap mental positif seseorang.

Sumber belajar lingkungan ini akan semakin memperkaya wawasan dan pengetahuan anak karena mereka belajar tidak terbatas oleh empat dinding kelas. Selain itu, kebenarannya lebih akurat sebab anak dapat mengalami secara langsung dan dapat mengoptimalkan potensi pancaindranya untuk berkomunikasi dengan lingkungan tersebut.

Menurut Dakir (2004: 2), kurikulum merupakan suatu program pendidikan yang berisikan berbagai bahan ajar dan pengalaman belajar yang diprogramkan, direncanakan, dan

dirancang secara sistematis atas dasar norma-norma yang berlaku yang dijadikan pedoman dalam proses pembelajaran bagi tenaga pendidik dan peserta didik untuk mencapai tujuan pendidik. 
Pembelajaran bahasa Indonesia dengan kurikulum 2013 merupakan pembelajaran berbasis teks, sehingga dalam pelaksanaannya guru membelajarkan siswa mengenai teks. Teks yang dipelajari salah satunya yaitu teks laporan hasil observasi. Teks laporan hasil observasi merupakan teks yang berisi penjabaran umum atau melaporkan sesuatu berupa hasil dari pengamatan (observasi). Teks laporan (report) ini juga disebut sebagai teks klasifikasi karena memuat klasifikasi mengenai jenis-jenis teks berdasarkan kriteria tertentu.

\section{METODE}

Pendekatan yang digunakan dalam penelitian ini adalah pendekatan kualitatif. Sukmadinata (dalam Pramono, 2020:3) mengatakan bahwa penelitian kualitatif merupakan penelitian untuk mendeskripsikan atau menganalisis pemikiran seseorang secara individu maupun kelompok serta fenomena lainnya. Penelitian kualitatif merupakan penelitian yang bertujuan untuk memahami kondisi suatu konteks dengan mengarahkan pada pendeskripsian secara rinci dan mendalam mengenai potret kondisi dalam suatu konteks yang alami (natural setting), tentang apa yang sebenarnya terjadi menurut apa adanya di lapangan studi. Penelitian dilaksanakan di kelas VII SMP Negeri 1 Telaga, Kecamatan Telaga, Kabupaten Gorontalo, Provinsi Gorontalo.

Data dalam penelitian ini adalah penerapan metode outdoor learning yang dilakukan oleh peneliti dalam pembelajaran bahasa Indonesia kelas VII Smp Negeri 1 Telaga. Sumber data dalam penelitian ini adalah peneliti yang mengajar bahasa Indonesia melalui Rencana Pelaksanaan Pembelajaran (RPP) dan buku Bahasa Indonesia.

Teknik pengumpulan data yang digunakan dalam penelitian ini adalah teknik observasi, wawancara, dan dokumentasi. Marshall (dalam Sugiyono, 2017:310) menyatakan bahwa melalui observasi, peneliti belajar tentang perilaku dan makna dari perilaku tersebut. Teknik wawancara tidak terstruktur digunakan apabila prakarsa untuk memilih topik bahasan wawancara dilakukan oleh siswa, atau orang yang diwawancarai (Syamsudin dan Damaianti, 2006: 239). Teknik dokumentasi menurut Basrowi dan Suwandi (2008: 158) merupakan suatu cara pengumpulan data yang menghasilkan catatan-catatan penting yang berhubungan dengan masalah yang diteliti. 


\section{HASIL DAN PEMBAHASAN}

\section{Hasil}

Penelitian tentang penerapan metode pembelajaran berbasis outdoor learning dalam pelajaran mengonstruksi teks laporan hasil observasi ini difokuskan pada tiga masalah, yaitu: (a) Bagaimanakah penerapan metode pembelajaran berbasis outdoor learning dalam pelajaran mengonstruksi teks laporan hasil observasi pada siswa kelas VII SMP Negeri 1 Telaga; (b) Bagaimanakah kendala yang dihadapi dalam penerapan metode pembelajaran berbasis outdoor learning dalam pelajaran mengonstruksi teks laporan hasil observasi pada siswa kelas VII SMP Negeri 1 Telaga; (c) Bagaimanakah upaya mengatasi masalah dalam penerapan metode pembelajaran berbasis outdoor learning dalam pelajaran mengonstruksi teks laporan hasil observasi pada siswa kelas VII SMP Negeri 1 Telaga.

Berdasarkan hasil observasi, pelaksanaan proses pembelajaran mengonstruksi teks laporan hasil observasi berdasarkan metode outdoor learning yang dilaksanakan oleh peneliti pada peserta didik kelas VII SMP Negeri 1 Telaga meliputi kegiatan (a) pendahuluan, (b) kegiatan inti, dan (c) kegiatan penutup.

Kegiatan awal pada pelaksanaan pembelajaran dilakukan di dalam kelas untuk melakukan apersepsi dan motivasi. Kegiatan apersepsi ini bertujuan untuk menggali pengetahuan siswa mengenai materi mengonstruksi teks laporan hasil observasi. Selain itu, peneliti juga memeriksa kehadiran dan kondisi siswa dan memotivasi mereka untuk membangkitkan semangat peserta didik dalam proses pembelajaran. Kegiatan pendahuluan atau kegiatan awal proses pembelajaran yang dilakukan oleh peneliti adalah seperti berdoa sebelum memulai kegiatan belajar dan mengecek kehadiran siswa.

Kegiatan inti meliputi materi ajar, penerapan outdoor learning, pemanfaatan sumber belajar atau media dalam pembelajaran, dan siswa dilibatkan dalam pembelajaran. Pada kegiatan inti ini, peserta didik harus mampu menentukan bagian-bagian dari struktur teks laporan hasil observasi yang terdiri dari bagian pendahuluan, isi, dan bagian penutup.

Tahap-tahap penerapan kegiatan belajar pada kegiatan inti dengan menggunakan metode outdoor learning berdasarkan tiga kelompok. Kelompok satu mendapat tema tentang 
lingkungan sekolah. Pada tahap pertama, peneliti mengamati kelompok satu yang sedang melakukan observasi tentang lingkungan sekolah. Pada tahap kedua, peserta didik diminta untuk mencatat temuan observasi tentang lingkungan sekolah yang telah peserta didik lihat dan amati di lingkungan sekolah. Pada tahap ketiga, peserta didik mulai menuliskan teks laporan hasil observasi tentang lingkungan sekolah di lembar kerja peserta didik. Setelah peserta didik menuliskan teks laporan hasil observasi tentang lingkungan, maka pada tahap selanjutnya peserta didik menentukan struktur teks laporan hasil observasi tentang lingkungan sekolah yang menjadi inti dari pembelajaran.

Kelompok dua mendapat tema tentang sampah di sekolah. Pada tahap pertama, peneliti mengamati kelompok dua yang sedang melakukan observasi tentang sampah di sekolah. Pada tahap kedua, peserta didik diminta untuk mencatat temuan observasi tentang sampah sekolah yang telah peserta didik lihat dan amati. Pada tahap ketiga, peserta didik mulai menuliskan teks laporan hasil observasi tentang sampah sekolah di lembar kerja peserta didik. Setelah peserta didik menuliskan teks laporan hasil observasi tentang sampah, maka pada tahap selanjutnya peserta didik menentukan struktur teks laporan hasil observasi tentang sampah sekolah yang menjadi inti dari pembelajaran.

Kelompok tiga mendapat tema tentang tumbuh-tumbuhan di sekolah. Pada tahap pertama, peneliti mengamati kelompok tiga yang sedang melakukan observasi tentang tumbuh-tumbuhan di sekolah. Pada tahap kedua, peserta didik diminta untuk mencatat temuan observasi tentang tumbuh-tumbuhan di sekolah yang telah peserta didik lihat dan amati. Pada tahap ketiga, peserta didik mulai menuliskan teks laporan hasil observasi tentang tumbuh-tumbuhan di sekolah di lembar kerja peserta didik. Setelah peserta didik menuliskan teks laporan hasil observasi tentang tumbuh-tumbuhan, maka pada tahap selanjutnya peserta didik menentukan struktur teks laporan hasil observasi tentang tumbuh-tumbuhan di sekolah yang menjadi inti dari pembelajaran. Setelah itu, peneliti memberikan arahan kepada peserta didik agar masuk ke kelas seperti semula. Setiap anggota kelompok mempresentasikan hasil kerja mereka. Sedangkan kelompok lain akan menanggapi dan bertanya tentang tema dari kelompok tersebut. Setelah presentasi masing-masing kelompok, peneliti memberikan refleksi kepada peserta didik tentang materi yang diajarkan. 
Berikut masing-masing penjelasan dari kegiatan penelitian tentang inti pembelajaran. (a) Menyampaikan materi dengan tujuan pembelajaran, mengaitkan materi dengan pengetahuan lain yang berhubungan dengan materi teks laporan hasil observasi yang akan diajarkan, dan memberikan materi pembelajaran dengan tepat dan sistematis. (b) Penerapan metode outdoor learning, yakni melaksanakan pembelajaran di luar kelas dengan KD dan tujuan yang akan dicapai. Penerapan metode outdoor learing dapat memberikan kesan yang baik untuk peserta didik dimana peserta didik berperan aktif dan berkarakteristik, dapat bekerja sama dalam kelompok, melaksanakan pembelajaran yang bersifat kontekstual, dan menyiapkan alokasi waktu yang sesuai dengan mata pelajaran bahasa Indonesia. (c) Menggunakan sumber belajar yang berada di luar kelas secara efektif dan efisien untuk mengajarkan tugas kelompok dan memberikan pesan yang menarik bagi peserta didik dalam pengalamannya. (d) Menumbuhkan partisipasi aktif pada peserta didik dalam pembelajaran teks laporan hasil observasi yang berada di dalam kelas maupun di luar kelas dan memberikan keceriaan pada peserta didik selama proses belajar di luar kelas. (e) Menggunakan bahasa lisan dan tulis secara jelas, baik, dan benar, menyampaikan pesan dengan gaya yang sesuai untuk membuat peserta didik lebih mudah menguasai materi yang diajarkan, memberikan motivasi pada peserta didik untuk mengembangkannya pada saat kegiatan pembelajaran selesai, dan memberikan kesimpulan yang menggambarkan pokok isi materi pembelajaran yang telah dipelajari.

Dalam penerapan metode outdoor learning, peneliti mengalami beberapa kendala seperti: (a) adanya covid-19 membuat peserta didik tidak boleh berlama-lama di sekolah; (b) waktu yang diberikan terlalu sedikit; (c) menemui peserta didik yang sulit untuk di berikan arahan; (d) mengondisikan kelas selama proses pembelajaran peserta didik; (e) kendala dari segi materi.

Upaya yang di lakukan peneliti dalam proses pelaksanaan pembelajaran meliputi: (a) upaya pemecahan masalah ditinjau dari sudut pandang peneliti yaitu mengondisikan waktu dan memperhatikan peserta didik untuk selalu memakai masker dan mencuci tangan tiap kali menyentuh sesuatu demi kenyamanan peserta didik. Dari penerapan metode outdoor learning dalam pembelajaran mengonstruksi teks laporan hasil observasi, peneliti 
memberikan pemahaman kepada peserta didik agar mereka tidak jenuh dan gaduh saat menerima materi dan mengerjakan tugas yang telah diberikan oleh peneliti; (b) manajemen waktu dalam penerapan metode outdoor learning sangat berpengaruh sehingga peneliti harus menyiapkan waktu khusus; (c) peneliti memberikan arahan kepada peserta didik yang lain agar tidak mengganggu kelas VII dalam proses pembelajaran sehingga proses belajar mengajar berjalan dengan baik dan peserta didik mulai belajar seperti semestinya; (d) Untuk menghindari penyebaran covid-19, peneliti menyelesaikan materi pembelajaran di dalam kelas agar peserta didik langsung ke luar dengan arahan dari peneliti. Dalam penerapan metode outdoor learning, peneliti memberikan arahan kepada peserta didik untuk mengerjakan materi kelompoknya yang sudah dibagi saat di dalam kelas; (e) dari segi materi, peneliti harus mampu menjelaskan materi berdasarkan langkah-langkahnya dari tahap awal sampai tahap akhir secara mendetail. Materi yang diberikan harus bervariasi sehingga peserta didik mudah untuk mengerti dan memahami materi yang dijelaskan.

Untuk meningkatkan hasil belajar peserta didik, maka peneliti menempuh beberapa upaya. Peneliti harus kreatif dalam mengembangkan materi untuk meningkatkan aktivitas belajar. Oleh karena itu, peneliti menerapkan metode outdoor learming agar siswa lebih aktif belajar.

\section{Pembahasan}

Hasil penelitian menunjukkan bahwa Rencana Pelaksanaan Pembelajaran (RPP) yang digunakan oleh peneliti dalam pembelajaran mengonstruksi teks laporan hasil observasi dengan metode outdoor learning pada peserta didik kelas VII5 Smp Negeri 1 Telaga sudah sesuai dengan proses pelaksanaan pembelajaran. Pada setiap tahap kegiatan, pembelajaran dengan metode outdoor learning yang di laksanakan sudah sesuai dengan yang tercantum di dalam Rencana Pelaksanaan Pembelajaran (RPP).

Pelaksanaan pembelajaran mengonstruksi teks laporan hasil observasi dengan metode outdoor learning pada peserta didik kelas VII SMP Negeri 1 Telaga mengindikasikan bahwa setiap tahap kegiatan sudah dilaksanakan oleh peneliti telah sesuai dengan Rencana Pelaksanaan Pembelajaran (RPP). Pada tahap kegiatan pendahuluan, peneliti melakukan 
apersepsi, menjelaskan materi, menyampaikan metode outdoor learning, dan membagi kelompok. Pada tahap kegiatan inti, peneliti memanfaatkan sumber/media di luar kelas, memberikan kesempatan kepada peserta didik untuk bertanya tentang teks laporan hasil observasi yang belum di pahami, dan memberikan kesempatan kepada kelompok untuk mempresentasikan kerja kelompok. Sebelum peneliti mengakhiri kegiatan pembelajaran, peneliti melaksanakan kegiatan refleksi dan memberikan kesimpulan materi yang telah diajarkan.

Berdasarkan beberapa hal yang telah diuraikan sebelumnya, dapat dikemukakan bahwa pembelajaran mengonstruksi teks laporan hasil observasi pada peserta didik kelas VII SMP Negeri 1 Telaga telah sesuai dengan Rencana Pelaksanaan Pembelajaran (RPP). Penerapan metode outdoor learning oleh peneliti dalam menyampaikan materi dapat dikatakan telah optimal.

\section{SIMPULAN}

Berdasarkan hasil penelitian dan pembahasan yang telah diuraikan pada bab sebelumnya, dapat disimpulkan bahwa penerapan metode pembelajaran berbasis outdoor learning dalam pembelajaran mengonstruksi teks laporan hasil observasi pada siswa kelas VII SMP Negeri 1 Telaga telah dilaksanakan oleh peneliti sesuai dengan Rencana Pelaksanaan Pembelajaran (RPP). Pada tahap kegiatan pendahuluan, peneliti melakukan apersepsi, menjelaskan materi, menyampaikan metode outdoor learning, dan membagi kelompok. Pada tahap kegiatan inti, peneliti memanfaatkan sumber/media di luar kelas, memberikan kesempatan kepada peserta didik untuk bertanya tentang teks laporan hasil observasi yang belum di pahami, dan memberikan kesempatan kepada kelompok untuk mempresentasikan kerja kelompok. Sebelum peneliti mengakhiri kegiatan pembelajaran, peneliti melaksanakan kegiatan refleksi dan memberikan kesimpulan materi yang telah diajarkan.

Selain itu, terdapat beberapa kendala yang dihadapi dalam penerapan metode pembelajaran berbasis outdoor learning. Kendala-kendala tersebut adalah peserta didik tidak boleh berlama-lama di sekolah karena adanya covid-19, waktu yang diberikan terlalu sedikit, 
terdapat peserta didik yang sulit untuk di berikan arahan, selama proses pembelajaran peserta didik kelas harus dikondisikan, dan kendala dari segi materi ajar.

Untuk mengatasi kendala-kendala tersebut, peneliti menempuh beberapa upaya. Upaya-upaya tersebut adalah pengondisian waktu dan pengarahan kepada peserta didik untuk selalu memakai masker dan mencuci tangan tiap kali menyentuh sesuatu demi kenyamanan peserta didik dan pemberian pemahaman kepada peserta didik agar mereka tidak jenuh dan gaduh saat menerima materi dan mengerjakan tugas yang telah diberikan oleh peneliti. Selain itu, peneliti juga melakukan manajemen waktu dalam penerapan metode outdoor learning dengan menyiapkan waktu khusus. Untuk mengatasi gangguan dari luar, peneliti mengarahkan peserta didik yang lain untuk tidak mengganggu kelas VII dalam proses pembelajaran sehingga proses belajar mengajar berjalan dengan baik dan peserta didik mulai belajar sebagaimana mestinya. Untuk menghindari penyebaran covid-19, peneliti menyelesaikan materi pembelajaran di dalam kelas agar peserta didik langsung ke luar dengan arahan dari peneliti. Dari segi materi, peneliti harus mampu menjelaskan materi mulai dari tahap awal sampai tahap akhir secara mendetail. Selain itu, materi yang diberikan juga harus bervariasi sehingga peserta didik mudah untuk memahami materi yang dijelaskan.

\section{DAFTAR RUJUKAN}

Basrowi, dan Suwandi. 2008. Memahami Penelitian Kualitatif. Jakarta: Rineka Cipta.

Dakhir. 2004. Perencanaan dan pengembangan kurikulum. Jakarta: Rineka Cipta

Husamah. 2013. Pembelajaran luar kelas Outdoor Learning. Jakarta: Prestasi Pustakarya.

Pramono, Rivan. 2020. Penerapan Metode Outdoor Learning dalam Pembelajaran Mengkonstruksi Teks Eksplanasi Pada Peserta Didik Kelas XI Sma Negeri 1 Godong Grobogan Tahun Pelajaran 2019/2020. Dwijaloka Volume 1, Nomor. 1.

Sugiyono, 2017. Metode Penelitian Pendidikan. Bandung: Alfabeta.

Syamsudin A.R, M.S dan Damaianti, Vismai. 2006. Metode penelitian Pendidikan Bahasa. Bandung: Remaja Rosdakarya.

Yumnah, Siti. dkk. 2019. Outdoor Learning Belajar di Luar kelas. Malang: Literasi Nusantara. 